\title{
Perspektif Siswa Terhadap E-Learning Berdasarkan Model Motivasi ARCS
}

\author{
Ita Chairun Nissa ${ }^{1}$, Baiq Rika Ayu Febrilia ${ }^{2}$, Fitri Astutik ${ }^{3}$ \\ ${ }^{1,2}$ Program Studi Pendidikan Matematika, Universitas Pendidikan Mandalika \\ ${ }^{3}$ Program Studi Pendidikan Teknologi Informasi, Universitas Pendidikan Mandalika \\ Penulis Korespondensi: itachairunnissa@ikipmataram.ac.id
}

\begin{abstract}
This study aims to measure the level of motivation of students who have implemented distance learning with E-Learning. This type of research is a survey because it uses a questionnaire as the main data collection instrument. The statement in the questionnaire refers to the ARCS Motivation Model by Keller on four elements, namely Attention, Relevance, Confidence, and Satisfaction. The validity test by two experts stated that the questionnaire was very valid with few revisions. Respondents were 42 students of class XI SMA Islam Al-Azhar NW Kayangan West Lombok where their teachers had received training using E-Learning, especially the Google Classroom platform in 2020. Questionnaire data were analyzed quantitatively and expressed in the form of frequency distribution and motivation criteria for each ARCS element. The presentation of quantitative data is then equipped with a description of the students' reasons when choosing a particular answer. Students' perspectives on E-Learning according to the ARCS Motivation Model in this study were divided into two types of responses, namely student responses to the learning experience using E-Learning and student responses to the availability of features/applications/media in E-Learning. Based on the average final score for each ARCS element, it can be concluded that students' responses to the learning experience using E-Learning on the Attention, Relevance, Confidence, and Satisfaction elements are all in good criteria. Meanwhile, students' responses to the availability of features/applications/media in E-Learning on the elements of Attention, Relevance, and Satisfaction are in poor criteria except for the Confidence element which is in good criteria.
\end{abstract}

Keywords: ARCS Model of Motivation, E-Learning, Student Perspective

Abstrak: Penelitian ini bertujuan untuk mengukur tingkat motivasi siswa yang telah melaksanakan pembelajaran jarak jauh dengan E-Learning. Jenis penelitian adalah survei karena menggunakan kuesioner sebagai instrument pengumpul data yang utama. Pernyataan dalam kuesioner merujuk pada Model Motivasi ARCS oleh Keller pada empat elemen yaitu Attention, Relevance, Confidence, dan Satisfaction. Uji validitas oleh dua ahli menyatakan bahwa kuesioner adalah sangat valid dengan sedikit revisi. Responden adalah 42 siswa kelas XI SMA Islam Al-Azhar NW Kayangan Lombok Barat dimana guru mereka telah mendapatkan pelatihan menggunakan E-Learning khususnya platform Google Classroom pada tahun 2020 lalu. Data kuesioner dianalisa secara kuantitatif dan dinyatakan dalam bentuk distribusi frekuensi dan kriteria motivasi untuk setiap elemen ARCS. Penyajian data kuantitatif ini kemudian dilengkapi dengan deskripsi alasan siswa pada saat memilih suatu jawaban tertentu. Perspektif siswa terhadap E-Learning menurut Model Motivasi ARCS pada penelitian ini terbagi dalam dua jenis respon yaitu respon siswa terhadap pengalaman belajar menggunakan E-Learning dan respon siswa terhadap ketersediaan fitur/aplikasi/media dalam E-Learning. Berdasarkan rata-rata skor akhir pada setiap elemen ARCS dapat disimpulkan bahwa respon siswa terhadap pengalaman belajar menggunakan $E$ Learning pada elemen Attention, Relevance, Confidence, dan Satisfaction semuanya berada pada kriteria baik. Sedangkan respon siswa terhadap ketersediaan fitur/aplikasi/media dalam E-Learning pada elemen Attention, Relevance, dan Satisfaction berada pada kriteria tidak baik kecuali elemen Confidence yang berada pada kriteria baik.

Kata kunci: Model Motivasi ARCS, E-Learning, Perspektif Siswa

\section{PENDAHULUAN}

Penelitian ini dilatarbelakangi oleh pelatihan E-Learning dengan Google Classroom yang pernah diberikan kepada guru SMA Islam Al-Azhar NW Kayangan 
Lombok Barat pada tahun 2020 yang lalu. Pelatihan itu diberikan untuk mengatasi masalah guru yang belum memiliki keterampilan cara menggunakan platform pembelajaran online untuk mendukung pembelajaran jarak jauh di masa pandemik COVID-19. Hasil pelatihan menunjukkan bahwa guru SMA Islam Al-Azhar NW Kayangan telah mampu menggunakan fitur-fitur Google Classroom seperti membuat kelas, mengatur materi yang diunggah, bahkan membuat tugas dan soal ujian secara online. Namun, keberhasilan guru dan siswa dalam melaksanakan E-Learning ini perlu dievaluasi untuk mengetahui kekuatan dan kelemahan pengajaran yang mungkin muncul selama proses pelaksanaan E-Learning tersebut. Hasil evaluasi ini tentunya akan memberikan masukan yang berharga bagi rancangan pembelajaran jarak jauh yang lebih baik di masa yang akan datang, dimana moda pembelajaran seperti ini mungkin masih diterapkan selama masa pandemik COVID-19 belum dinyatakan selesai oleh pemerintah.

E-Learning merupakan salah satu jenis pembelajaran yang dapat digunakan oleh guru di masa pandemik COVID-19 agar tetap dapat melakukan proses belajar-mengajar dengan siswa walaupun dalam kondisi berjauhan. E-Learning dapat didefinisikan sebagai suatu pembelajaran yang didukung oleh perangkat dan media elektronik digital (Kumar Basak, Wotto, \& Bélanger, 2018). Secara tidak langsung pandemik COVID-19 mendorong penggunaan E-Learning di institusi pendidikan mulai pendidikan dasar hingga perguruan tinggi (Ebner et al., 2020). Perubahan pembelajaran dari tatap muka menjadi E-Learning mengakibatkan ada kebutuhan yang meningkat dari penyelenggara pendidikan dalam hal penggunaan teknologi. Penggunaan E-Learning ini tidak akan mengurangi waktu dan kualitas pembelajaran tetapi justru mendorong pembelajaran menjadi lebih aktif apalagi disertai pemahaman yang baik tentang teknologi (Harandi, 2015). Hal ini dapat mendorong motivasi siswa menjadi lebih tinggi untuk melanjutkan pembelajaran dengan kemampuannya sendiri (Harandi, 2015).

E-Learning telah menjadi metode pengajaran yang semakin populer baik untuk pendidikan maupun kursus/pelatihan. Sejalan dengan semakin terkenalnya E-Learning muncul kekhawatiran tentang kualitas E-Learning itu sendiri khususnya motivasi siswa yang menjadi faktor penentu apakah siswa akan bertahan atau meninggalkan pembelajaran (Kim \& Frick, 2011). Dalam proses belajar mengajar matematika secara tatap muka, kita sering menemui masalah yang sulit terkait kurangnya motivasi dan minat dari siswa. Di awal pembelajaraan siswa sering berasumsi bahwa matematika adalah pelajaran yang sulit, rumit, dan penuh dengan rumus-rumus yang harus dihafalkan (Wahyuningsih, Nissa, \& Yuntawati, 2019). Siswa tidak sepenuhnya mempelajari materi dengan baik sehingga mempengaruhi pemahaman konsep dasar matematika mereka. Hal inilah yang menjadi tantangan E-Learning dalam pembelajaran Matematika terlebih siswa juga harus menguasai teknologi (Umoh \& Akpan, 2014).

Salah satu strategi untuk menilai motivasi siswa dalam E-Learning adalah Model Motivasi ARCS (Attention, Relevance, Confidence, Satisfaction) oleh Keller oleh Keller. Model ini didasarkan pada gagasan bahwa ada empat elemen kunci dalam proses pembelajaran yang dapat mendorong atau menopang motivasi belajar siswa. Empat 
elemen kunci tersebut adalah Attention, Relevance Confidence, dan Satisfaction (Keller, 2015). Model ini digunakan karena paling terkenal di kalangan peneliti dan pengajar. Keutamaan model ini adalah adanya pemetaan pedagogi tertentu ke masing-masing elemen menjadi sub-komponen sehingga guru dapat mendiagnosis kekurangan dari suatu pengajaran (Reynolds, Roberts, \& Hauck, 2017). Dengan demikian penelitian ini dilakukan untuk mendeskripsikan respon siswa terhadap E-Learning menurut model Motivasi ARCS (Attention, Relevance, Confidence, Satisfaction). Hasil penelitian ini diharapkan dapat memberikan konstribusi yang membangun dalam refleksi pembelajaran dan perancangan pengajaran di masa yang akan datang.

\section{METODE}

Jenis penelitian ini adalah penelitian survei karena peneliti menghimpun informasi dari para responden menggunakan kuesioner sebagai alat pengumpul data yang pokok. Kuesioner yang digunakan dalam penelitian ini adalah gabungan bentuk tertutup dan terbuka. Kuesioner tertutup memuat pernyataan-pernyataan yang dimodifikasi dari Model Motivasi ARCS oleh Keller (2015), sedangkan bentuk terbuka memuat pertanyaan agar siswa memberikan alasan atas pilihan jawabannya. Model Motivasi ARCS oleh Keller menilai motivasi siswa dalam E-Learning dalam empat elemen kunci yaitu Attention (perhatian), Relevance (Relevansi), Confidence (kepercayaan diri), dan Satisfaction (kepuasan). Setiap elemen ARCS diturunkan menjadi komponenkomponen penting yang merupakan strategi dalam mencapai elemen tersebut. Pada penelitian ini kami merancang dua pernyataan untuk masing-masing komponen. Pernyataan pertama ditujukan untuk menggali pengalaman siswa selama melakukan $E$ Learning, khususnya melalui platform Google Classroom, sedangkan pernyataan kedua ditujukan untuk mengetahui ketersediaan fitur/aplikasi/media dalam E-Learning. Tabel 1 s.d Tabel 4 berikut ini menyajikan pernyataan-pernyataan kuesioner menggunakan Model Motivasi ARCS.

Tabel 1. Pernyataan Kuesioner Model Motivasi ARCS pada Elemen Attention

\begin{tabular}{|c|c|}
\hline Komponen & Penyataan \\
\hline $\begin{array}{l}\text { 1. Partisipasi } \\
\text { aktif }\end{array}$ & $\begin{array}{l}\text { a. Saya melakukan permainan/tugas/praktik yang membuat saya tetap aktif } \\
\text { selama pembelajaran jarak jauh. } \\
\text { b. E-Learning didukung fitur/aplikasi/media untuk permainan/tugas/praktik } \\
\text { secara virtual. }\end{array}$ \\
\hline $\begin{array}{l}\text { 2. Penggunaan } \\
\text { humor }\end{array}$ & $\begin{array}{l}\text { a. Saya merasa senang dengan pembelajaran ini karena diselingi humor tetapi } \\
\text { tetap sopan dan santun. } \\
\text { b. E-Learning didukung fitur/aplikasi/media untuk menyajikan cerita humor } \\
\text { pendek/ringan kepada siswa }\end{array}$ \\
\hline $\begin{array}{l}\text { 3. Penggunaan } \\
\text { konflik }\end{array}$ & $\begin{array}{l}\text { a. Saya merasa tertantang dengan materi yang saya pelajari karena } \\
\text { bertentangan dengan pengetahuan saya saat ini. } \\
\text { b. E-Learning didukung fitur/aplikasi/media untuk menyajikan } \\
\text { masalah/konflik yang bertentangan dengan pengetahuan saya saat ini. }\end{array}$ \\
\hline $\begin{array}{l}\text { 4. Penggunaan } \\
\text { variasi }\end{array}$ & $\begin{array}{l}\text { a. Saya merasa pembelajaran ini menarik, menyenangkan, dan tidak } \\
\text { membosankan. } \\
\text { b. E-Learning didukung dengan fitur/aplikasi/multimedia yang menarik dan } \\
\text { bervariasi. }\end{array}$ \\
\hline $\begin{array}{l}\text { 5. Contoh } \\
\text { nyata }\end{array}$ & $\begin{array}{l}\text { a. Saya merasa materi yang saya pelajari dapat diterapkan dalam kehidupan } \\
\text { sehari-hari dan bidang pekerjaan di masa depan. }\end{array}$ \\
\hline
\end{tabular}


b. E-Learning didukung fitur/aplikasi/media untuk menyajikan berbagai contoh penerapan materi dalam dunia nyata.

Tabel 2. Pernyataan Kuesioner Model Motivasi ARCS pada Elemen Relevance

\begin{tabular}{|c|c|}
\hline Komponen & Pernyataan \\
\hline $\begin{array}{l}\text { 1. Relevan dengan } \\
\text { pengetahuan } \\
\text { sebelumnya }\end{array}$ & $\begin{array}{l}\text { a. Saya merasa materi yang sedang saya pelajari relevan dengan } \\
\text { pengetahuan saya sebelumnya. } \\
\text { b. E-Learning didukung fitur/aplikasi/media yang menunjukkan relevansi } \\
\text { antara pengetahuan lama dengan pengetahuan baru. }\end{array}$ \\
\hline $\begin{array}{l}\text { 2. Relevan dengan } \\
\text { kondisi/masalah } \\
\text { saat ini }\end{array}$ & $\begin{array}{l}\text { a. Saya merasa materi yang saya pelajari relevan dengan kondisi/masalah } \\
\text { kehidupan saat ini. } \\
\text { b. E-Learning didukung fitur/aplikasi/media yang menunjukkan relevansi } \\
\text { antara materi pelajaran dengan kondisi/masalah kehidupan saat ini. }\end{array}$ \\
\hline $\begin{array}{l}\text { 3. Relevan dengan } \\
\text { manfaat di masa } \\
\text { depan }\end{array}$ & $\begin{array}{l}\text { a. Saya merasa materi yang saya pelajari relevan dengan manfaat atau } \\
\text { bidang kehidupan di masa depan. } \\
\text { b. E-Learning didukung fitur/aplikasi/media yang menyajikan relevansi } \\
\text { antara materi pelajaran dengan manfaat di masa depan. }\end{array}$ \\
\hline 4. Pemodelan & $\begin{array}{l}\text { a. Saya belajar bagaimana menunjukkan pengetahuan/keterampilan yang } \\
\text { saya miliki dengan mengamati presentasi guru, siswa lain atau presentasi } \\
\text { saya sendiri. } \\
\text { b. E-Learning didukung fitur/aplikasi/media untuk aktivitas presentasi } \\
\text { guru dan siswa. }\end{array}$ \\
\hline 5. Pilihan & $\begin{array}{l}\text { a. Saya diberikan pilihan untuk belajar sesuai dengan metode atau media } \\
\text { yang saya inginkan. } \\
\text { b. E-Learning didukung fitur/aplikasi/media yang dapat memfasilitasi } \\
\text { perbedaan cara belajar siswa. }\end{array}$ \\
\hline
\end{tabular}

Tabel 3. Respon Siswa atas Pernyataan Kuesioner pada Elemen Confidence

\begin{tabular}{|c|c|}
\hline Komponen & Pernyataan Kuesioner \\
\hline $\begin{array}{l}\text { 1. Memfasilitasi } \\
\text { perkembangan } \\
\text { diri }\end{array}$ & $\begin{array}{l}\text { a. Saya mendapatkan informasi mengenai perkembangan hasil belajar saya } \\
\text { atau laporan nilai tugas dan tes secara berkala. } \\
\text { b. E-Learning didukung fitur/aplikasi/media untuk memantau perkembangan } \\
\text { hasil belajar siswa. }\end{array}$ \\
\hline $\begin{array}{l}\text { 2. Mengkomunika } \\
\text { sikan tujuan dan } \\
\text { prasyarat }\end{array}$ & $\begin{array}{l}\text { a. Saya memahami apa yang harus dicapai setelah mempelajari suatu materi } \\
\text { dan apa pengetahuan prasyarat yang harus saya kuasai untuk mempelajari } \\
\text { materi tersebut. } \\
\text { b. Fitur/aplikasi/media dalam E-Learning yang digunakan selama ini } \\
\text { mendukung cara guru untuk mengkomunikasikan tujuan dan prasyarat } \\
\text { pembelajaran. }\end{array}$ \\
\hline $\begin{array}{l}\text { 3. Menyediakan } \\
\text { umpan balik }\end{array}$ & $\begin{array}{l}\text { a. Saya mendapatkan umpan balik yang konstruktif untuk meningkatkan } \\
\text { hasil belajar saya. } \\
\text { b. Fitur/aplikasi/media dalam E-Learning yang digunakan selama ini } \\
\text { mendukung cara guru untuk memberikan umpan balik kepada siswa. }\end{array}$ \\
\hline $\begin{array}{l}\text { 4. Memberikan } \\
\text { kendali pada } \\
\text { siswa }\end{array}$ & $\begin{array}{l}\text { a. Saya mengerti apa yang ingin saya ketahui dari materi yang sedang } \\
\text { dipelajari, seperti apa manfaaat yang ingin saya dapatkan dan bagaimana } \\
\text { cara memperolehnya. } \\
\text { b. E-Learning didukung fitur/aplikasi/media untuk memberikan kendali } \\
\text { kepada siswa atas beberapa aktivitas atau metode pembelajaran. }\end{array}$ \\
\hline
\end{tabular}

Tabel 4. Pernyataan Kuesioner Model Motivasi ARCS pada Elemen Satisfaction

\begin{tabular}{|c|c|}
\hline Komponen & Pernyataan \\
\hline $\begin{array}{l}\text { 1. Hadiah atau } \\
\text { penghargaan }\end{array}$ & $\begin{array}{l}\text { a. Saya mendapatkan penghargaan atas hasil kerja saya. Penghargaan ini } \\
\text { dalam bentuk poin pencapaian, stiker kemajuan atau pujian dari guru atau } \\
\text { siswa lain. }\end{array}$ \\
\hline & $\begin{array}{l}\text { b. E-Learning didukung oleh fitur/aplikasi/media untuk memberikan } \\
\text { penghargaan kepada siswa yang dapat dilihat oleh semua anggota kelas. }\end{array}$ \\
\hline 2. Aplikasi yang & a. Saya dapat dengan segera mengaplikasikan materi yang telah saya \\
\hline
\end{tabular}


segera dapat

dirasakan pelajari dalam pemecahan masalah kehidupan nyata.

b. E-Learning ini mudah digunakan, efektif untuk mencapai tujuan pembelajaran serta efisien dalam waktu dan biaya.

Sebelum digunakan sebagai instrumen penelitian, kuesioner tersebut diuji validitasnya berdasarkan penilaian dua orang ahli sebagai validator. Indikator penilaian kuesioner merujuk pada aturan pembuatan kuesioner menurut Acharya (2010). Aturan ini fokus pada sepuluh hal yang tidak boleh dilakukan saat merancang pernyataan dalam kuesioner. Pemberian skor merujuk pada modifikasi skala Likert empat skala penilaian yaitu sangat setuju (skor 4), setuju (skor 3), tidak setuju (skor 2), dan sangat tidak setuju (skor 1). Persentase rata-rata skor dari kedua ahli kemudian dikonsultasikan ke Tabel 5 untuk memutuskan kriteria validitas dan apakah kuesioner memerlukan revisi besar, revisi kecil atau tidak memerlukan revisi sama sekali (Wulanzani, Lestari, \& Syamsyuri, 2016).

Tabel 5. Kriteria Validitas Instrumen

\begin{tabular}{lll}
\hline Skor & Keputusan & Saran \\
\hline $\bar{x} \leq 60 \%$ & Cukup Valid & Perlu revisi besar \\
$60 \%<\bar{x} \leq 80 \%$ & Valid & Perlu revisi kecil \\
$80 \%<\bar{x} \leq 100 \%$ & Sangat Valid & Perlu revisi kecil atau tidak perlu revisi sama sekali \\
\hline $\bar{x}=$ persentase rata - rata skor yang diberikan validator
\end{tabular}

Kuesioner yang telah dinyatakan valid kemudian dibagikan kepada 42 orang siswa kelas XI SMA Islam NW Al-Azhar Kayangan Lombok Barat. Data kuesioner dianalisis secara kuantitatif menggunakan Microsoft Excel versi 2010. Pemberian skor kuesioner juga merujuk pada modifikasi skala Likert empat skala penilaian yaitu sangat setuju (skor 4), setuju (skor 3), tidak setuju (skor 2), dan sangat tidak setuju (skor 1). Pengolahan data kuesioner ditampilkan dalam format distribusi frekuensi dan hasilnya dikonsultasikan kepada Tabel 6 untuk menentukan kriteria setiap pernyataan angket (Fajri, Purwandari, \& Coastera, 2018), sedangkan jawaban siswa atas pertanyaan terbuka dideskripsikan secara naratif.

Tabel 6. Kriteria Respon Angket

\begin{tabular}{lll}
\hline Skor kriterium & Skala penilaian & Kriteria \\
\hline $4 \times 42=168$ & $127-168$ & Sangat Baik \\
$3 \times 42=126$ & $85-126$ & Baik \\
$2 \times 42=84$ & $43-84$ & Tidak Baik \\
$1 \times 42=42$ & $0-42$ & Sangat Tidak Baik \\
\hline
\end{tabular}

\section{HASIL DAN PEMBAHASAN}

Pada bagian ini ditunjukkan hasil penelitian terkait dua hal yaitu hasil validitas instrumen kuesioner dan hasil tanggapan siswa sebagai responden kuesioner. Pertama, uji validitas terhadap kuesioner dilakukan berdasarkan penilaian dua orang ahli masingmasing pada bidang pendidikan matematika dan bidang teknologi informasi. Hasil validitas kuesioner ditunjukkan pada Tabel 3 di bawah ini. 
Tabel 7. Hasil Uji Validitas Kuesioner

\begin{tabular}{llll}
\hline \multirow{2}{*}{ No } & Indikator & \multicolumn{2}{c}{ Skor } \\
\cline { 3 - 4 } & Tidak ada pernyataan tanpa tujuan & 4 & 3 \\
2 & Tidak ada bahasa yang rumit & 3 & 3 \\
3 & Tidak ada konsep yang ambigu & 3 & 3 \\
4 & Tidak ada pernyataan yang mengarahkan jawaban & 4 & 4 \\
5 & Tidak ada pernyataan yang menyinggung responden & 4 & 4 \\
6 & Tidak ada pernyataan dengan kalimat panjang yang membingungkan & 2 & 3 \\
7 & Tidak ada penggabungan dua/lebih pernyataan berbeda dalam satu kalimat & 3 & 3 \\
8 & Tidak ada kalimat negatif ganda & 3 & 4 \\
9 & Tidak ada pernyataan yang memuat perhitungan rumit & 4 & 4 \\
10 & Tidak ada pernyataan yang bergantung pada pernyataan sebelumnya & 4 & 4 \\
\hline & Persentase rata-rata skor & $85 \%$ & $87.5 \%$ \\
& Kriteria validitas & Sangat & Sangat \\
& & Valid & Valid \\
& Saran dari ahli I : beberapa kalimat masih dapat dibuat dengan kalimat yang lebih pendek
\end{tabular}

Berdasarkan data pada Tabel 7 diketahui bahwa kedua ahli menyatakan bahwa kuesioner berada pada kriteria sangat valid dan dapat digunakan sebagai instrumen dalam penelitian ini dengan sedikit revisi. Pengambilan data dalam penelitian dilakukan ini dengan membagikan kuesioner secara online kepada siswa dalam bentuk google form. Kuesioner ini dibagikan oleh guru mata pelajaran melalui grup whatsapp kelas dengan link https://forms.gle/2L947w2VueKoMFeM7. Data kuesioner dianalisa secara terpisah untuk nomor komponen bagian a dan nomor komponen bagian $b$ untuk mengetahui secara spesifik bagaimana repon siswa terhadap pengalaman belajar jarak jauh melalui E-Learning dan bagaimana ketersediaan fitur/aplikasi/media dalam $E$ learning yang mendukung motivasi siswa melakukan pembelajaran jarak jauh. Tabel 8 berikut ini menunjukkan rekapitulasi data kuesioner untuk nomor komponen bagian a.

Tabel 8. Hasil Kuesioner ARCS pada Komponen dan Nomor Pernyataan Bagian a

\begin{tabular}{|c|c|c|c|c|c|c|c|c|c|c|c|c|}
\hline \multirow{2}{*}{$\begin{array}{l}\text { Elemen } \\
\text { ARCS }\end{array}$} & \multirow{2}{*}{\multicolumn{2}{|c|}{$\begin{array}{c}\text { Komponen dan } \\
\text { nomor pernyataan }\end{array}$}} & \multicolumn{4}{|c|}{ Jumlah respon } & \multicolumn{4}{|c|}{$\begin{array}{l}\text { Jumlah respon } \mathrm{x} \\
\text { bobot skor }\end{array}$} & \multirow{2}{*}{$\begin{array}{l}\text { Skor } \\
\text { total }\end{array}$} & \multirow{2}{*}{$\begin{array}{c}\text { Kri } \\
\text { teria }\end{array}$} \\
\hline & & & SS & $\mathbf{S}$ & TS & STS & SS & $\mathbf{S}$ & TS & STS & & \\
\hline \multirow[t]{6}{*}{ Attention } & $\begin{array}{l}\text { Partisipasi } \\
\text { aktif }\end{array}$ & 1.a & 13 & 19 & 10 & 0 & 52 & 57 & 20 & 0 & 129 & $\begin{array}{l}\text { Sangat } \\
\text { Baik }\end{array}$ \\
\hline & $\begin{array}{l}\text { Penggunaan } \\
\text { humor }\end{array}$ & 2.a & 3 & 5 & 20 & 14 & 12 & 15 & 40 & 14 & 81 & $\begin{array}{l}\text { Tidak } \\
\text { Baik }\end{array}$ \\
\hline & $\begin{array}{l}\text { Penggunaan } \\
\text { konflik }\end{array}$ & 3.a & 9 & 12 & 16 & 5 & 36 & 36 & 32 & 5 & 109 & Baik \\
\hline & $\begin{array}{l}\text { Penggunaan } \\
\text { variasi }\end{array}$ & 4.a & 2 & 6 & 21 & 13 & 8 & 18 & 42 & 13 & 81 & $\begin{array}{l}\text { Tidak } \\
\text { Baik }\end{array}$ \\
\hline & Contoh nyata & $5 . \mathrm{a}$ & 10 & 17 & 11 & 4 & 40 & 51 & 22 & 4 & 117 & Baik \\
\hline & \multicolumn{10}{|c|}{ Rata-rata skor } & 103.4 & Baik \\
\hline \multirow[t]{2}{*}{ Relevance } & $\begin{array}{l}\text { Relevan dgn } \\
\text { pengetahuan } \\
\text { sebelumnya }\end{array}$ & 1.a & 8 & 28 & 6 & 0 & 32 & 84 & 12 & 0 & 128 & $\begin{array}{l}\text { Sangat } \\
\text { Baik }\end{array}$ \\
\hline & $\begin{array}{l}\text { Relevan dgn } \\
\text { kondisi saat ini }\end{array}$ & 2.a & 5 & 16 & 18 & 3 & 20 & 48 & 36 & 3 & 107 & Baik \\
\hline
\end{tabular}




\begin{tabular}{|c|c|c|c|c|c|c|c|c|c|c|c|c|}
\hline & $\begin{array}{l}\text { Relevan dgn } \\
\text { manfaat di } \\
\text { masa depan }\end{array}$ & 3.a & 8 & 15 & 15 & 4 & 32 & 45 & 30 & 4 & 111 & Baik \\
\hline & Pemodelan & $4 . \mathrm{a}$ & 0 & 10 & 28 & 4 & 0 & 30 & 56 & 4 & 90 & Baik \\
\hline & Pilihan & 5.a & 0 & 0 & 35 & 7 & 0 & 0 & 70 & 7 & 77 & $\begin{array}{c}\text { Tidak } \\
\text { Baik }\end{array}$ \\
\hline & \multicolumn{10}{|c|}{ Rata-rata skor } & 102.6 & Baik \\
\hline \multirow[t]{5}{*}{ Confidence } & $\begin{array}{l}\text { Memfasilitasi } \\
\text { perkembangan } \\
\text { diri }\end{array}$ & 1.a & 0 & 25 & 17 & 0 & 0 & 75 & 34 & 0 & 109 & Baik \\
\hline & $\begin{array}{l}\text { Mengkomuni- } \\
\text { kasikan tujuan } \\
\text { dan prasyarat }\end{array}$ & 2.a & 9 & 21 & 9 & 3 & 36 & 63 & 18 & 3 & 120 & Baik \\
\hline & $\begin{array}{l}\text { Memberikan } \\
\text { umpan Balik }\end{array}$ & 3.a & 2 & 20 & 18 & 2 & 8 & 60 & 36 & 2 & 106 & Baik \\
\hline & $\begin{array}{l}\text { Kendali pada } \\
\text { siswa }\end{array}$ & 4.a & 0 & 9 & 22 & 11 & 0 & 27 & 44 & 11 & 82 & $\begin{array}{l}\text { Tidak } \\
\text { Baik } \\
\end{array}$ \\
\hline & \multicolumn{10}{|c|}{ Rata-rata skor } & 104.3 & Baik \\
\hline \multirow[t]{3}{*}{ Satisfaction } & $\begin{array}{l}\text { Hadiah/ } \\
\text { penghargaan }\end{array}$ & 1.a & 10 & 21 & 11 & 0 & 40 & 63 & 22 & 0 & 125 & Baik \\
\hline & $\begin{array}{l}\text { Aplikasi yang } \\
\text { segera } \\
\text { dirasakan }\end{array}$ & 2.a & 0 & 5 & 25 & 12 & 0 & 15 & 50 & 12 & 77 & $\begin{array}{l}\text { Tidak } \\
\text { Baik }\end{array}$ \\
\hline & \multicolumn{10}{|c|}{ ata skor } & 101 & Baik \\
\hline
\end{tabular}

Data pada Tabel 8 menunjukkan kepada kita bahwa pengalaman belajar siswa selama melakukan pembelajaran jarak jauh dengan fasilitas E-Learning khususnya platform Google Classroom bervariasi mulai dari kriteria sangat baik, baik hingga tidak baik. Komponen partisipasi aktif berada pada kriteria "sangat baik" karena siswa banyak mengerjakan tugas-tugas dari sekolah. Namun, siswa merasa pembelajaran seperti itu kurang menarik dan membosankan. Hal ini nampak pada komponen "penggunaan variasi" yang berada pada kriteria tidak baik. Walaupun siswa tetap aktif selama pembelajaran jarak jauh namun aktivitas mereka cenderung monoton. Siswa membaca materi dan menonton video namun minim aktivitas permainan atau praktik. Siswa memang perlu difasilitasi dengan media yang bervariasi agar siswa tidak merasa jenuh dan bosan dalam belajar (Nugraha, 2018). Selain itu komunikasi antara guru dan siswa cenderung hanya sebatas memberikan instruksi pembelajaran tanpa diselingi humor atau pembicaraan ringan yang menyenangkan. Hal ini nampak pada komponen "penggunaan humor" yang berada pada kriteria tidak baik. Sesekali menggunakan humor ringan sebenarnya penting untuk membuat siswa tetap merasa senang dan termotivasi dalam pembelajaran jarak jauh yang penuh dengan keterbatasan. Humor memiliki peranan penting dalam pembentukan kecerdasan emosi siswa dan suasana interaksi yang menyenangkan sehingga kehadiran guru selalu dinanti walaupun dalam kondisi yang tidak dapat bertatap muka (Nani, Hamid, \& Bahara, 2018).

Dalam hal pengelolaan materi dan aktivitas pembelajaran, guru sangat baik dalam menghubungkan pengetahuan siswa sebelumnya dengan materi yang akan dipelajari. Hal ini nampak pada komponen "relevan dengan pengetahuan sebelumnya" yang berada pada kriteria sangat baik. Dengan cara seperti ini siswa dapat melihat relevansi antara materi terdahulu dengan materi yang baru. Pembelajaran menjadi semakin menantang pada saat guru menyajikan suatu situasi yang bertentangan dengan pengetahuan siswa saat ini atau suatu masalah yang menimbulkan konflik dalam pemikiran siswa. Hal ini nampak pada komponen "penggunaan konflik", komponen "contoh nyata", dan 
komponen "relevan dengan kondisi saat ini" yang ketiganya berada pada kriteria baik. Guru menggunakan media video untuk menjelaskan hal tersebut yang dilengkapi juga dengan penjelasan tentang manfaatnya di masa depan. Namun, konten video masih belum menjangkau aplikasi langsung yang dapat diterapkan siswa dalam kehidupan sehari-hari. Hal ini nampak pada komponen "aplikasi yang segera dirasakan" yang berada pada kriteria tidak baik. Siswa menyatakan bahwa mereka telah memahami materi dengan baik tetapi masih mengalami kesulitan apabila diminta untuk menerapkannya secara langsung.

Motivasi siswa dalam E-Learning juga dipengaruhi oleh bagaimana guru memberikan model kesuksesan kepada siswa dan hal ini nampak pada komponen "pemodelan" yang berada pada kriteria baik. Siswa memberikan respon yang baik karena mereka dapat melihat guru mereka sendiri melakukan presentasi materi seperti yang terjadi di dalam kelas. Namun di sisi lain siswa menyatakan bahwa mereka sendiri tidak pernah melakukan suatu presentasi selama pembelajaran jarak jauh ini berlangsung. Siswa hanya sebatas menonton video presentasi dari guru. Hal lain yang tak kalah penting dalam menentukan motivasi siswa adalah pemberian umpan balik dan penghargaan atas pencapaian kinerja siswa. Seringkali guru memberikan latihan atau tugas yang terlalu banyak selama melaksanakan pembelajaran jarak jauh sehingga umpan balik sangat diperlukan siswa untuk mempertahankan motivasi belajar mereka (Sapta, 2012). Pada komponen ini guru telah melakukannya dengan baik dengan memberikan informasi secara berkala kepada siswa mengenai kehadiran, nilai tugas dan nilai ujian. Guru juga memberikan kata-kata pujian sebagai bentuk penghargaan kepada siswa yang tetap aktif mengikuti pembelajaran jarak jauh. Hal ini ditunjukkan pada komponen "memfasilitasi perkembangan diri", komponen "memberikan umpan balik", dan komponen 'hadiah/penghargaan" yang ketiganya berada pada kriteria baik.

Berdasarkan uraian di atas dapat dikatakan bahwa pengalaman siswa belajar jarak jauh menggunakan E-Learning secara umum adalah baik walaupun masih ada beberapa komponen yang perlu diperbaiki di masa depan. Dalam pelaksanaannya, E-Learning ini tentu harus didukung oleh seperangkat teknologi yang dapat memfasilitasi semua elemen yang diperlukan untuk mempertahankan atau meningkatkan motivasi belajar siswa. Oleh karena itu, Tabel 9 berikut ini menampilkan hasil respon siswa tentang ketersediaan fitur/aplikasi/media dalam E-Learning yang digunakan selama ini.

Tabel 9. Hasil Kuesioner ARCS pada Komponen dan Nomor Pernyataan Bagian b

\begin{tabular}{|c|c|c|c|c|c|c|c|c|c|c|c|c|}
\hline \multirow{2}{*}{$\begin{array}{l}\text { Elemen } \\
\text { ARCS }\end{array}$} & \multirow{2}{*}{\multicolumn{2}{|c|}{$\begin{array}{c}\text { Komponen dan } \\
\text { nomor pernyataan }\end{array}$}} & \multicolumn{4}{|c|}{ Jumlah respon } & \multicolumn{4}{|c|}{$\begin{array}{c}\text { Jumlah respon } \mathrm{x} \\
\text { bobot skor }\end{array}$} & \multirow{2}{*}{$\begin{array}{l}\text { Skor } \\
\text { total }\end{array}$} & \multirow{2}{*}{$\begin{array}{c}\text { Krite } \\
\text { ria }\end{array}$} \\
\hline & & & SS & $\mathbf{S}$ & TS & STS & $\mathbf{S S}$ & $\mathbf{S}$ & TS & STS & & \\
\hline \multirow[t]{6}{*}{ Attention } & $\begin{array}{l}\text { Partisipasi } \\
\text { aktif }\end{array}$ & $1 . b$ & 2 & 4 & 28 & 8 & 8 & 12 & 56 & 8 & 84 & $\begin{array}{l}\text { Tidak } \\
\text { Baik }\end{array}$ \\
\hline & $\begin{array}{l}\text { Penggunaan } \\
\text { humor }\end{array}$ & 2.b & 0 & 5 & 25 & 12 & 0 & 15 & 50 & 12 & 77 & $\begin{array}{l}\text { Tidak } \\
\text { Baik }\end{array}$ \\
\hline & $\begin{array}{l}\text { Penggunaan } \\
\text { konflik }\end{array}$ & 3.b & 0 & 14 & 18 & 10 & 0 & 42 & 36 & 10 & 88 & Baik \\
\hline & $\begin{array}{l}\text { Penggunaan } \\
\text { variasi }\end{array}$ & 4.b & 0 & 5 & 22 & 15 & 0 & 15 & 44 & 15 & 74 & $\begin{array}{l}\text { Tidak } \\
\text { Baik }\end{array}$ \\
\hline & Contoh nyata & $5 . b$ & 0 & 8 & 22 & 14 & 0 & 24 & 44 & 14 & 82 & $\begin{array}{l}\text { Tidak } \\
\text { Baik }\end{array}$ \\
\hline & \multicolumn{10}{|c|}{ Rata-rata skor } & 81 & $\begin{array}{l}\text { Tidak } \\
\text { Baik }\end{array}$ \\
\hline Relevance & $\begin{array}{l}\text { Relevan } \\
\text { dengan }\end{array}$ & 1.b & 6 & 20 & 10 & 6 & 24 & 60 & 20 & 6 & 110 & Baik \\
\hline
\end{tabular}




\begin{tabular}{|c|c|c|c|c|c|c|c|c|c|c|c|c|}
\hline & \multicolumn{12}{|l|}{$\begin{array}{l}\text { pengetahuan } \\
\text { sebelumnya }\end{array}$} \\
\hline & $\begin{array}{l}\text { Relevan } \\
\text { dengan kondisi } \\
\text { saat ini }\end{array}$ & 2.b & 0 & 15 & 17 & 10 & 0 & 45 & 34 & 10 & 89 & Baik \\
\hline & $\begin{array}{l}\text { Relevan } \\
\text { dengan } \\
\text { manfaat di } \\
\text { masa depan }\end{array}$ & 3.b & 0 & 0 & 24 & 18 & 0 & 0 & 48 & 18 & 66 & $\begin{array}{l}\text { Tidak } \\
\text { Baik }\end{array}$ \\
\hline & Pemodelan & $4 . b$ & 0 & 10 & 24 & 8 & 0 & 30 & 48 & 8 & 86 & Baik \\
\hline & Pilihan & 5.b & 0 & 0 & 30 & 12 & 0 & 0 & 60 & 12 & 72 & $\begin{array}{l}\text { Tidak } \\
\text { Baik } \\
\end{array}$ \\
\hline & \multicolumn{10}{|c|}{ Rata-rata skor } & 84.6 & $\begin{array}{l}\text { Tidak } \\
\text { Baik }\end{array}$ \\
\hline \multirow[t]{5}{*}{ Confidence } & $\begin{array}{l}\text { Memfasilitasi } \\
\text { perkembangan } \\
\text { diri }\end{array}$ & 1.b & 5 & 20 & 15 & 5 & 20 & 60 & 24 & 5 & 109 & Baik \\
\hline & $\begin{array}{l}\text { Mengkomuni- } \\
\text { kasikan tujuan } \\
\text { dan prasyarat }\end{array}$ & 2.b & 0 & 10 & 20 & 12 & 0 & 30 & 40 & 12 & 82 & $\begin{array}{l}\text { Tidak } \\
\text { Baik }\end{array}$ \\
\hline & $\begin{array}{l}\text { Memberikan } \\
\text { umpan Balik }\end{array}$ & 3.b & 5 & 18 & 13 & 6 & 20 & 54 & 26 & 6 & 106 & Baik \\
\hline & $\begin{array}{l}\text { Kendali pada } \\
\text { siswa }\end{array}$ & 4.b & 0 & 5 & 29 & 8 & 0 & 15 & 58 & 8 & 81 & $\begin{array}{l}\text { Tidak } \\
\text { Baik }\end{array}$ \\
\hline & \multicolumn{10}{|c|}{ Rata-rata skor } & 94.5 & Baik \\
\hline \multirow[t]{3}{*}{ Satisfaction } & $\begin{array}{l}\text { Hadiah/ } \\
\text { penghargaan }\end{array}$ & 1.b & 0 & 15 & 20 & 7 & 0 & 45 & 40 & 7 & 92 & Baik \\
\hline & $\begin{array}{l}\text { Aplikasi yang } \\
\text { segera } \\
\text { dirasakan }\end{array}$ & 2.b & 0 & 0 & 32 & 10 & 0 & 0 & 64 & 10 & 74 & $\begin{array}{l}\text { Tidak } \\
\text { Baik }\end{array}$ \\
\hline & \multicolumn{10}{|c|}{ Rata-rata skor } & 83 & $\begin{array}{l}\text { Tidak } \\
\text { Baik }\end{array}$ \\
\hline
\end{tabular}

Data pada Tabel 9 menunjukkan kepada kita bahwa ketersediaan fitur/aplikasi/media dalam E-Learning didominasi oleh kriteria tidak baik walaupun ada beberapa komponen yang berada pada kriteria baik. Untuk komponen yang dinilai siswa dengan tidak baik disebabkan karena belum ada fitur atau aplikasi untuk mendukung apa yang diinginkan siswa dari pembelajaran. Misalnya belum ada aplikasi permainan atau praktik yang dapat dimainkan secara virtual oleh siswa, termasuk belum ada video atau aplikasi untuk menyajikan humor atau cerita ringan berkaitan dengan materi yang dipelajari. Padahal penggunaan permainan atau praktik matematika dalam pembelajaran dapat meningkatkan kemampuan menghitung, membangkitkan motivasi, dan memunculkan inisiatif dalam pemecahan masalah (Hakim \& Sari, 2019). Selain itu juga belum tersedia video atau aplikasi yang dapat memberikan siswa gambaran nyata manfaat materi di masa depan atau penerapan materi yang dapat langsung diterapkan dalam kehidupan sehari-hari. Penyajian materi baik melalui video atau buku elektronik oleh guru masih sebatas membahas konsep dan contoh penerapan rumus matematika.

Tidak semua komponen mendapatkan penilaian yang tidak baik dari siswa. Komponen-komponen terkait dengan penyajian materi dan refleksi atas kinerja siswa berhasil dinilai baik oleh siswa. Guru berhasil memfasilitasi siswa melalui video untuk 
menghubungkan pengetahuan siswa sebelumnya dengan materi yang akan dipelajari dan menunjukkan relevansinya dengan kondisi saat ini. Guru juga dapat mengkomunikasikan tujuan pembelajaran dan materi prasyarat melalui fitur pengumuman, obrolan atau komentar yang ada dalam platform Google Classroom. Perkembangan diri siswa juga telah difasilitasi dengan baik melalui fitur penilaian, komentar pribadi dan pengembalian tugas atau ujian. Di sini guru dan siswa dapat saling berkomunikasi untuk mendiskusikan kelemahan atau kekuatan dari tugas atau ujian yang telah dikerjakan.

Dengan memperhatikan data dan argumentasi yang telah diberikan oleh siswa maka secara keseluruhan dapat dikatakan bahwa masih perlu dilakukan perbaikan atau peningkatan pada aspek pengelolaan materi yang secara tidak langsung nantinya dapat mempengaruhi motivasi siswa pada setiap elemen ARCS. Pada beberapa penelitian diketahui bahwa siswa, guru, atau perancang instruksional sepakat bahwa penyajian konten materi pelajaran dalam E-Learning adalah hal yang sangat penting untuk mempertahankan atau meningkatkan motivasi siswa yang sedang melakukan pembelajaran dengan teknologi (Hassan, et al., 2012). Konten materi pelajaran dapat disajikan melalui gamifikasi/permainan/praktik virtual. Gamifikasi dalam Model Motivasi ARCS dapat dilakukan dalam bentuk permainan interaktif dimana siswa dapat memilih tugas yang akan dikerjakan, dan apabila permainan ini sering dilakukan maka dapat membangun motivasi intrinsik dan penalaran (Jusuf, 2016). Selain penggunaan permainan, penting juga untuk merancang konten materi dalam E-Learning yang relevan dengan pengetahuan siswa sebelumnya, saat ini, dan masa depan. Kesenjangan pengetahuan siswa pada ketiga tahap tersebut dapat mempengaruhi peluang keberhasilan siswa dalam pembelajaran (Derr, Hübl, \& Ahmed, 2018).

\section{SIMPULAN DAN SARAN}

Perspektif siswa terhadap E-Learning menurut Model Motivasi ARCS pada penelitian ini terbagi dalam dua jenis respon yaitu respon siswa terhadap pengalaman belajar menggunakan E-Learning dan respon siswa terhadap ketersediaan fitur/aplikasi/media dalam E-Learning. Berdasarkan rata-rata skor akhir pada setiap elemen ARCS dapat disimpulkan bahwa respon siswa terhadap pengalaman belajar menggunakan $E$ Learning pada elemen Attention, Relevance, Confidence, dan Satisfaction semuanya berada pada kriteria baik. Sedangkan respon siswa terhadap ketersediaan fitur/aplikasi/media dalam E-Learning pada elemen Attention, Relevance, dan Satisfaction berada pada kriteria tidak baik kecuali elemen Confidence yang berada pada kriteria baik. Hasil penelitian ini tentu dipengaruhi beberapa kondisi yang tidak dapat dikendalikan oleh peneliti seperti situasi pada saat siswa mengisi kuesioner yang tidak dapat dipantau secara langsung oleh peneliti karena kuesioner dikirimkan secara online. Selain itu karena fokus penelitian adalah data terkait E-Learning jadi pernyataan kuesioner tidak dikhususkan pada topik matematika tertentu. Respon siswa terkait hal ini tentu akan sangat bervariasi karena pengalaman belajar matematika pada topik yang satu akan berbeda dengan pengalaman belajar matematika pada topik lainnya. 


\section{UCAPAN TERIMA KASIH}

Terima kasih disampaikan kepada LPPM UNDIKMA sebagai sponsor, SMA Islam AlAzhar NW Kayangan sebagai mitra, dan semua pihak yang membantu proses penelitian.

\section{DAFTAR PUSTAKA}

Acharya, B. (2010). Questionnaire design. In Periodica Polytechnica Electrical Engineering (Vol. 33). https://doi.org/10.2307/2965735

Derr, K., Hübl, R., \& Ahmed, M. Z. (2018). Prior knowledge in mathematics and study success in engineering : informational value of learner data collected from a webbased pre-course. European Journal of Engineering Education, 43(6), 911-926. https://doi.org/10.1080/03043797.2018.1462765

Ebner, M., Schön, S., Braun, C., Ebner, M., Grigoriadis, Y., Haas, M., ... Taraghi, B. (2020). COVID-19 epidemic as E-learning boost? Chronological development and effects at an Austrian university against the background of the concept of "Elearning readiness." Future Internet, 12(6), 1-20. https://doi.org/10.3390/FI12060094

Fajri, A., Purwandari, E. P., \& Coastera, F. F. (2018). Metode algoritma dijkstra (Studi kasus: kelurahan kandang limun dan beringin raya). Jurnal Rekursif, 6(1), 69-79.

Hakim, D. L., \& Sari, R. M. M. (2019). Aplikasi game matematika dalam meningkatkan kemampuan menghitung matematis. Jurnal Penelitian Dan Pembelajaran Matematika, 12(1), 129-141. https://doi.org/10.30870/jppm.v12i1.4860

Harandi, S. R. (2015). Effects of e-learning on students' motivation. Procedia - Social and Behavioral Sciences, 181(1), 423-430. https://doi.org/10.1016/j.sbspro.2015.04.905

Hassan, H., Hassan, F., Omar, N. D. @ , Zakaria, Z., \& Nor, W. A. W. M. (2012). Evaluating mathematics e-learning materials: Do evaluators agree with distance learners? Procedia - Social and Behavioral Sciences, 67(1), 189-195. https://doi.org/10.1016/j.sbspro.2012.11.320

Hr, B. M., Pratama, I. A., \& Munawarah, P. A. (2020). Efektivitas pembelajaran fully daring terhadap kemampuan penalaran matematis siswa. Media Pendidikan Matematika, 8(2), 31-42.

Jusuf, H. (2016). Penggunaan gamifikasi dalam proses pembelajaran. Jurnal TICOM, $5(1), 1-6$.

Keller, J. (2015). Instructional design models and theories: Keller's ARCS model of motivation (web publication). https://doi.org/10.4018/978-1-7998-1542-6.ch005

Kim, K. J., \& Frick, T. (2011). Changes in student motivation during online learning. Journal of Educational Computing Research, 44(1), 1-23. https://doi.org/10.2190/EC.44.1.a

Kumar Basak, S., Wotto, M., \& Bélanger, P. (2018). E-learning, M-learning and Dlearning: Conceptual definition and comparative analysis. E-Learning and Digital Media, 15(4), 191-216. https://doi.org/10.1177/2042753018785180

Nani, K. La, Hamid, I., \& Bahara, S. R. (2018). Pengembangan model cettar membahana dalam pembelajaran matematika. Jurnal Matematika Dan Pendidikan Matematika, 7(1), 47-64.

Nugraha, M. (2018). Manajemen kelas dalam meningkatkan proses pembelajaran. Tarbawi: Jurnal Keilmuan Manajemen Pendidikan, 4(1), 27. 
https://doi.org/10.32678/tarbawi.v4i01.1769

Reynolds, K. M., Roberts, L. M., \& Hauck, J. (2017). Exploring motivation : Integrating the ARCS model with instruction. In Reference Services Review.

Sapta, A. (2012). Perbedaan hasil belajar matematika siswa yang diberi umpan balik berupa angka saja dengan umpan balik berupa angka disertai komentar. Jurnal Agmasu Research, I(1), 85-92. Retrieved from https://osf.io/preprints/inarxiv/f379d/

Setiawandi, A., Hernawan, A., \& Chotimah, S. (2019). Analisis kepercayaan diri siswa SMA IT Fithrah Insani Bandung menggunakan media ICT berbasis for VBA Excel pada materi persamaan kuadrat. Media Pendidikan Matematika, 7(2), 10. https://doi.org/10.33394/mpm.v7i2.2187

Umoh, J. B., \& Akpan, E. T. (2014). Challenges of blended E-learning tools in mathematics: students' perspectives University of Uyo. Journal of Education and Learning, 3(4), 60-70. https://doi.org/10.5539/jel.v3n4p60

Wahyuningsih, H., Nissa, I. C., \& Yuntawati, Y. (2019). Analisis kemampuan siswa dalam memahami konsep Sistem Persamaan Linier Tiga Variabel (SPLTV) berdasarkan teori APOS siswa kelas X IPS 1 MA Tarbiyatul Mustafid Batu Rimpang. Media Pendidikan Matematika, 7(1), 36. https://doi.org/10.33394/mpm.v7i1.1556

Wulanzani, U. T., Lestari, U., \& Syamsyuri, I. (2016). Hasil validasi buku teks matakuliah biotekologi berbasis bahan alam tanaman pacing (costus speciosus smith) sebagai antifertilitas. Jurnal Pendidikan: Teori, Penelitian, Dan Pengembangan, 1(9), 1830-1835. 


\section{Lampiran: Teori Model Motivasi ARCS oleh Keller}

John M. Keller adalah pendiri Model Motivasi ARCS. Model ini didasarkan pada gagasan bahwa ada empat elemen kunci dalam proses pembelajaran yang dapat mendorong atau menopang motivasi belajar siswa. Empat elemen kunci tersebut adalah Attention, Relevance Confidence, dan Satisfaction yang disingkat menjadi ARCS. Keller menjelaskan masing-masing elemen tersebut dengan beberapa strategi E-Learning yang perlu diketahui oleh para perancang instruktusional professional untuk mengembangkan E-Learning yang benar-benar menarik.

\section{Model ARCS: Attention}

Keller menyarankan bahwa perhatian dapat diperoleh melalui perceptual arousal atau inquiry arousal. Pada kasus perceptual arousal, perhatian siswa akan diperoleh melalui kejutan, keraguan atau ketidakpercayaan. Sedangkan untuk inquiry arousal, keingintahuan siswa distimulasi melalui masalah menantang yang perlu dipecahkan.

\section{Active participation}

Melalui permainan, bermain peran atau jenis hand-on praktik, siswa didorong menjadi peserta aktif dalam proses pembelajaran. Semakin siswa terlibat aktif dalam proses pembelajaran, mereka akan cenderung tertarik dengan konten E-Learning dan ada peluang lebih tinggi untuk dapat menyelesaikan E-Learning dengan sukses.

2. Use of humor

Perancang pengajaran untuk E-Learning dapat memasukkan cerita humor pendek atau humor ringan untuk menarik perhatian siswa. Namun perlu diingat menggunakan humor dalam pembelajaran harus dilakukan dengan hati-hati.

\section{Conflict}

Teknik lainnya yang digunakan untuk mendapatkan perhatian siswa adalah dengan cara menyajikan pernyataan atau fakta yang mungkin bertentangan/kontradiksi dengan pengetahuan yang telah dimiliki siswa atau keyakinan yang selama ini dianggap benar. Hal ini akan menarik perhatian siswa karena mereka ingin mempelajari lebih lanjut tentang topik yang sedang didiskusikan.

\section{Variety}

Perancang pengajaran untuk E-Learning juga dapat menarik perhatian siswa dengan menggunakan berbagai media yang berbeda. Menyajikan semua informasi dengan cara yang sama akan membosankan bagi siswa. Menggunakan berbagai alternatif bentuk presentasi merupakan strategi yang pasti dapat membuat E-Learning lebih menarik.

5. Real world examples

Secara umum, siswa menjadi lebih termotivasi jika mereka percaya bahwa apa yang mereka pelajari memiliki aplikasi praktis dalam kehidupan nyata. Memberi tahu siswa tentang aplikasi praktis dari materi yang disajikan melalui E-Learning dalam kehidupan sehari-hari mereka baik pribadi maupun bidang professional, dengan menggunakan kisah atau contoh kehidupan nyata, akan menarik perhatian siswa dan membuat mereka ingin tahu lebih banyak.

\section{Model ARCS: Relevance}

Desain E-Learning yang sukses harus menetapkan relevansi untuk memotivasi siswa. Untuk mencapai hal ini, profesional E-Learning didorong untuk menggunakan bahasa, 
analogi, atau cerita yang dapat dihubungkan oleh pelajar. Strategi relevansi berikut disarankan oleh Keller di Model Motivasi ARCS.

\section{Link to previous example}

Ini merupakan suatu strategi motivasi yang sangat sukses karena hal ini akan memungkinkan siswa untuk membangun koneksi dari informasi baru yang disajikan dengan apa yang mereka sudah ketahui dari pengalaman sebelumnya. Strategi ini memberi siswa kesan/rasa "kontinuitas" yang membuat mereka tetap termotivasi karena siswa telah benar-benar memperluas pengetahuan dasar mereka. Ketika siswa percaya bahwa belajar adalah suatu keberhasilan dan tidak membuang-buang waktu maka siswa akan tetap terlibat dalam E-Learning dimana hal ini sekarang dianggap sebagai salah satu faktor motivasi teratas.

2. Perceived present worth

Siswa biasanya termotivasi menghadiri E-Learning saat mereka benar-benar membutuhkannya, yaitu saat pengetahuan dan keterampilan baru diperlukan agar siswa dapat menghadapi situasi tertentu di masa depan atau masalah yang sedang mereka hadapi saat ini dalam kehidupan nyata. Siswa menjadi lebih termotivasi jika mereka melihat hubungan langsung bagaimana E-Learning yang mereka ikuti akan membekali mereka dengan keterampilan baru yang akan membantu mereka dalam menyelesaikan masalah.

3. Perceived future usefulness

Sejauh mana siswa percaya pada bagaimana kelas dalam E-Learning akan membantu mereka dalam kehidupan di kemudian hari adalah faktor penentu penting mengenai seberapa besar motivasi siswa untuk hadir dalam E-Learning. Jadi, perancang instruksional harus mengkomunikasikan pesan ini sejak awal.

\section{Modelling}

Dengan cara guru memberikan contoh presentasi atau menawarkan presentasi kepada siswa sendiri dapat menunjukkan kepada siswa terhadap model kesuksesan dalam belajar. Dengan melihat presentasi orang lain (guru atau siswa lain) yang berhasil menerapkan pengetahuan atau keterampilan tertentu, siswa akan termotivasi dan memiliki persepsi bahwa kelas dalam E-Learning adalah bermanfaat bagi pengembangan diri mereka sendiri.

\section{Choice}

Memberikan pilihan kepada siswa atas strategi instruksional mereka sendiri adalah faktor lain yang dapat meningkatkan motivasi. Ini terjadi karena ketika siswa pada masa sekarang ini mengetahui apa yang ingin mereka pelajari dan bagaimana caranya. Siswa memiliki preferensi pada suatu metode atau media pembelajaran tertentu yang mungkin akan lebih efektif dibandingkan dengan yang lain.

\section{Model ARCS: Confidence}

Perancang instruksional harus menanamkan rasa percaya diri pada siswa dengan membantu mereka untuk percaya bahwa siswa dapat sukses dalam belajar. Jika siswa merasa seolah-olah mereka tidak dapat mencapai tujuan mereka, maka hal ini akan mengurangi motivasi mereka. Berikut adalah beberapa cara yang dapat direncanakan oleh perancang instruksional dalam E-Learning yang dapat meningkatkan tingkat kepercayaan diri siswa:

\section{Facilitate self growth}

Dorong siswa untuk mengambil langkah-langkah kecil dan segera tunjukkan kemajuan mereka dalam E-Learning. Ini akan memotivasi siswa dengan membantu 
mereka percaya pada diri mereka sendiri dimana hasil ini dimaknai dengan pertumbuhan diri.

2. Communicate objectives and prerequisites

Sangat penting bagi siswa untuk mengetahui sebelumnya apa yang sebenarnya harus mereka capai dalam kelas E-Learning. Menyadari bahwa siswa dapat mencapai tujuan dan sasaran dari kelas E-Learning merupakan faktor penentu motivasi mereka. Juga sangat penting bagi pengajar untuk mengetahui apa yang diharapkan dari siswa dalam kelas E-Learning dan bagaimana tepatnya siswa akan dievaluasi di akhir pembelajaran.

3. Provide feedback

Umpan balik adalah penentu penting lainnya dari motivasi siswa. Mengetahui posisi siswa dalam kemajuan belajarnya adalah penting bagi siswa untuk melanjutkan pembelajaran dalam E-Learning. Jika tidak ada umpan balik yang diberikan maka siswa akan merasa bingung karena siswa tidak yakin tentang kemajuan mereka dalam E-Learning. Umpan balik, terutama yang konstruktif, penting untuk mendorong siswa melanjutkan kepercayaan diri untuk aktivitas E-Learning berikutnya atau untuk meninjau aktivitas sebelumnya, Umpan balik yang membangun dapat memperkuat perilaku positif dan keterampilan siswa.

4. Give learners control

Dengan memberikan beberapa kendali kepada siswa atas proses pembelajaran akan memberi siswa pemahaman mengenai kemerdekaan dalam belajar dan bahwa siswa dapat mengendalikan kesuksesan mereka sendiri. Dengan kata lain, itu membuat siswa percaya bahwa siswa bertanggung jawab atas pembelajaran mereka sendiri. Dengan membiarkan siswa memilih metode pembelajaran yang mereka anggap lebih cocok dapat memotivasi mereka untuk berkomitmen dalam kelas E-Learning karena ini adalah strategi yang secara aktif melibatkan siswa dalam proses pembelajaran.

\section{Model ARCS: Satisfaction}

Komponen terakhir dari Model Motivasi ARCS oleh Keller adalah kepuasan. Model ARCS ini menyajikan hubungan langsung antara kepuasan dan tingkat motivasi belajar siswa baik secara intrinsik maupun ekstrinsik. Siswa harus merasa bangga dan puas atas apa yang telah mereka capai selama berlangsungnya kelas dalam E-Learning. Berikut ini strategi bagaimana perancang instruksional dapat mengadaptasi ke arah ini.

1. Praise or rewards

Proses pembelajaran harus memberikan siswa semacam penghargaan yang dapat dinyatakan dalam bentuk poin pencapaian atau pujian dari pengajar. Kedua hal itu dapat meningkatkan tingkat kepuasan siswa atas E-Learning karena mereka akan merasakan pencapaian dan pengakuan atas upaya mereka selama proses pembelajaran.

2. Immediate application

Siswa seharusnya merasa seolah-olah keterampilan atau materi yang mereka kuasai akan berguna dalam pembelajaran di masa depan. Ini dapat dicapai dengan mendorong siswa untuk menerapkan pengetahuan dan keterampilan yang baru mereka peroleh dalam aplikasi dunia nyata atau dengan cara melibatkan siswa dalam aktivitas pemecahan masalah nyata. Ini akan memberi siswa kepuasan secara mental karena mereka akan merasa bahwa waktu, biaya, dan upaya belajar mereka selama ini dalam E-Learning adalah berharga dan bermanfaat. 